\title{
EMISSION-OFFSET BANKING: ACGOMMODATING INDUSTRIAL GROWTH WITH AIR-QUALITY STANDARDS
}

Although most everyone, including economists, has traditionally viewed the air we breathe as a "free good," 1 polluted air may soon become a high-priced commodity. Already, advertisements like the following appear in the financial press:

For Sale: Substantial Hydrocarbon Emission Offset in the Chicago area. For details, contact Box EZ-300, Wall Street Journal. $^{2}$

This advertisement was placed by a woodfinishing plant whose impending closing would reduce air pollution in Chicago by about 1600 tons of emissions per year. It has been estimated that this reduction may be worth as much as $\$ 3000$ per ton to a buyer desiring to construct or expand an industry in Chicago. ${ }^{3}$

Such large-scale trading is the result of the "offset policy" introduced in $1976^{4}$ by the Environmental Protection Agency (EPA) as part of a steadily increasing federal effort to balance stringent airpollution control with the need for continued industrial growth. ${ }^{\mathbf{5}}$ Under this policy, when EPA determines that the air quality in a particular region is below acceptable standards, additional polluters are barred, making it extremely difficult for industries to construct new plants or expand existing ones in that area. If a company, however, is able to "offset" the pollution from its proposed plantfor example, by paying for improved controls on existing plants in the area or by purchasing an old facility like the woodfinishing plant above and shutting it down-the air-pollution level would remain constant, and the EPA would permit the new plant to open.

1 Comment, Who Owns the Air? The Emission Offet Concept and Its Implications, 9 ENVT'L L. 575, 589 (1979).

2 Mother Jones, Nov. 1979, at 12.

$3 I d$.

4 Air Quality Standards; Interpretative Ruling, 41 Fed. Reg. 55,524 (1976), revised at 44 Fed. Reg. 3,274 (1979) (to be codified in 40 C.F.R. $\$ 51$ ) (hereinafter cited as 1976 Offset Ruling].

5 Kramer, The 1977 Clean Air Act Amendments: A Tactical Retreat From the Technology-Forcing Strategy?, 15 URB. L. ANN. 103, 120 n.83 (1978); Comment, supra note 1 , at 578 . 
This policy of accommodation ${ }^{6}$ has been considerably expanded in the Emission Offset Ruling, ${ }^{7}$ promulgated ${ }^{8}$ in January, 1979, which permits existing sources actually to "bank" offsets for future use or sale. Thus, sources which do not merely attain but actually reduce their emissions below an assigned maximum are permitted to "bank" the difference between their new output level and the required level. ${ }^{9}$ The 1979 offset ruling would permit these sources to save their offsets in a state-administered "account" ${ }^{10}$ despite the agency's original conviction that such offsets should be turned immediately to productive uses, creating jobs, rather than be stored "idly." 11

EPA's about-face with regard to offset banking greatly enhances the prospect for a fully developed emissions-rights market in which offsets are bought and sold or sometimes held for speculation.12 Unfortunately, the 1979 ruling does not explain why the agency's original concerns have been allayed. After describing the banking policy in detail in part $I$, this Comment will consider some of these concerns in part II. By identifying the potential pitfalls of offset banking, the remainder of the Comment shows the importance of determining the precise legal status of offsets. The Comment will finally suggest, in part IV(C), that, rather than being treated as purely private or purely public property, emission offsets should be treated as licenses in a manner roughly analogous to the treatment of the public airwaves. Such an analysis provides a legal framework, where none now exists, for dealing with offsets in an effective and principled fashion.

6 Examples of major offset transactions under the 1976 Offset Ruling are documented in Comment, supra note 1 , at 593-94.

744 Fed. Reg. 3,274 (1979) (to be codified in 40 C.F.R. $\$ 51$ ) [hereinafter cited as 1979 Offset Ruling]. The details of the revised ruling are canvassed fully in Raffle, Prevention of Significant Deterioration and Non-attainment Under the Clean Air Act, 10 ENvrR. Rep. (BNA), Monograph No. 27 (1979). This new ruling reverses the position taken in 1976. See 1976 Offset Ruling, supra note 4, at 55,529.

8 The revisions to the offset policy were published as an interpretative ruling. The Manufacturing Chemists Ass'n. (MCA) has brought suit against EPA, claiming that the new offset policy is not simply a revision of an interpretative ruling but rather is a policy revision which requires a notice-and-comment period under the Administrative Procedure Act, 5 U.S.C. \$553 (1976). See Record, Manufacturing Chemists Ass'n v. EPA, No. 79-1112 (D.C. Cir., filed Jan. 29, 1979) [hereinafter cited as MCA Record].

91979 Offset Ruling, supra note 7, at 3,285.

$10 \mathrm{Id}$.

11 See text accompanying notes 37-41 infra.

12 See J. Quafues, Federal Regulation of New Industruad Prants 73 (1979); Comment, supra note 1 , at $594 \& 595$ n.110. 


\section{The Genesis of the Emission-Offret Ruling and}

\section{OTFSET BANIKING}

\section{A. The Offet Policy Takes Shape}

Under the Glean Air Act, ${ }^{13}$ primary responsibility for attainment of national ambient air quality standards (NAAQS) ${ }^{14}$ resides with the states, which are required to develop separate State Implementation Plans (SIPs) setting the control strategies to reduce air pollution. ${ }^{15}$ Among other things, the SIPs are to specify the permissible levels of pollution that stationary sources may emit ${ }^{10}$ and to designate air quality control regions (AQCRs) in which those limits will apply. ${ }^{17}$ The control strategies provide for reduction of overall pollution levels or of the rate of pollution output sufficient to meet the NAAQS within statutory deadlines. ${ }^{18}$

When the Glean Air Act Amendments of 1970 were enacted, ${ }^{19}$ the principal concern was the protection of public health against high concentrations of air pollution. ${ }^{20}$ Expecting great progress in a short time, Congress set 1975 as the deadline for attainment of the NAAQS. By 1975, however, it was evident that Congress had been overly optimistic. The steel industry, for example, had no plants in compliance with the pollution-control requirements by that time. ${ }^{21}$ Over fifty cities exceeded the NAAQS for carbon monoxide; indeed, many had violations for several types of pollutants at once. ${ }^{22}$ Clearly, it would have been impossible for all AQCRs to

1342 U.S.C. $\$ \$ 7401-7626$ (Supp. I 1977).

14 NAAQSs have been established for the following pollutants: sulfur dioxide, nitrogen dioxide, carbon monoxide, hydrocarbons (a precursor to photochemical oxidants), particulate matter, and lead. See 40 C.F.R. $\$ 50$ (1978).

15 Clean Air Act $\$ \$ 107 \& 110,42$ U.S.C. $\$ \$ 7407 \& 7410$ (Supp. I 1977). New or extensively modified sources of air pollution are also required to meet federal new source performance standards (NSPS), expressed in terms of the results achievable by using the best available technology. Id. $\$ 111,42$ U.S.C. $\$ 7411$.

16 Id. $\$ 110(\mathrm{a})(2)(\mathrm{B}), 42$ U.S.C. $\$ 7410(\mathrm{a})(2)(\mathrm{B})$.

17 Id. $\$ 107,42$ U.S.C. $\$ 7407$.

18 The new deadline for attaining primary NAAQSs is December, 1982, for some pollutants, and December, 1987, for others. Id. $\oint 172(\mathrm{a})(1) \&(2), 42$ U.S.C. $\$ 7502(a)(1) \&(2)$.

19 Pub. L. No. 91-604, 84 Stat. 1676 (1970).

20 Clean Air Act $\$ 101$ (b)(1), 42 U.S.C. $\$ 7401$ (b)(I) (Supp. I 1977).

21 H.R. Rer. No. 294, 95th Cong., Ist Sess. 210-11, reprinted in [1977] U.S. Code Cong. \& AD. News 1289-90.

22 Id. 207-08, [1977] U.S. CoDE CoNG. \& AD. NEws at 1286-87 (quoting from letter from EPA Administrator Train to Sen. Muskie). Even as late as 1978, many, if not most, areas of the country which had been in violation of some standard were still considered nonattainment areas. For example, of 105 urban areas with a population greater than $200,000,103$ were in violation of the NAAQSs for photochemical oxidants. 43 Fed. Reg. 8,962-63 (1978). 
meet the statutory deadlines. Under the 1970 amendments, however, failure to attain NAAQS by 1975 meant that permits to construct new or modified sources could no longer issue. ${ }^{23}$ The potential for severe economic and social disruptions was great, especially because industrial expansion in the nation's principal industrial centers could have been halted altogether. ${ }^{24}$

EPA finally responded in 1976 by promulgating its Air Quality Standards Interpretative Ruling, ${ }^{25}$ which supplied a means of permitting new growth while theoretically assuring eventual attainment. The ruling established a permit requirement and provided that "major" ${ }^{26}$ new or modified sources, ${ }^{27}$ which would cause or aggravate violations of NAAQS in a nonattainment area, would be granted permits to operate only if they met several specific conditions, ${ }^{28}$ one of which bears directly on the issue of emission-offset

23 Clean Air Act $\$ 110$ (a)(4), 42 U.S.C. $\$ 7410$ (a)(4) (Supp. I 1977).

24 See Rosenberg \& Friedman, Air Quality and Industrial Growth: The Location of New Industrial Sources of Pollution in Non-Attainment Areas, 11 NAT. RESounces LAw. 523, 523-24 (1978).

251976 Offset Ruling, supra note 4, at 55,524.

26 Of course, the definition of "major source" is crucial. The 1979 offset ruling purports to adopt the statutory definition, Clean Air Act $\$ 302(j)$, 42 U.S.C. $\$ 7602$ (Supp. I 1977), and thus includes as "major sources" all those with "potential emissions of 100 tons or more per year." 1979 Offset Ruling, supra note 7, at 3,276 (emphasis added). Although the ruling invites further comment, it strongly favors classifying sources on the basis of their total emissions before the application of control equipment, id., thus significantly increasing the number of industries subject to the permit requirements. However, EPA's interpretation of the term "potential emissions" as meaning "uncontrolled emissions" was recently rejected by the District of Columbia Court of Appeals in Alabama Power Co. v. Costle, No. 78-1006, slip op. at 24-31 (D.C. Cir. Dec. 14, 1979) (Leventhal, J.), in which the agency's prevention of significant deterioration (PSD) regulations for attainment areas were extensively reviewed. "Potential," the court said, refers to the amount of emissions after the installation of pollution-control facilities. Although the decision does not bear directly on offset regulations, the fact that the offset regulations were expressly modeled after the PSD regulations suggests that an effect of Alabama Power may be to reduce the number of "major sources" subject to EPA's permit requirements in nonattainment areas.

At the same time, however, the court insisted that any modifications of such major sources which had the effect of increasing net pollution, no matter how slightly, were subject to PSD regulations. Again, this verdict will probably be applied in the nonattainment context as well because "modification" is defined similarly for both attainment and nonattainment areas. See Clean Air Act $\$ 171(4)$, 42 U.S.C. $\$ 7501$ (4) (Supp. I 1977).

27 For a discussion of the controversy over defining a "source," see Comment, supra note 1 , at 583 .

28 In addition to obtaining offsets, as described in the text, the new or modified source was required to meet standards for the lowest achievable emission rate (LAER), which was defined as either the most stringent emission limitation contained in the SIP of any state for the same type of source or the most stringent limitation achieved in practice by that type of source, whichever is more stringent. 1976 Offset Ruling, supra note 4, at 55,528. Second, the new-source applicant had to certify that "all existing sources owned or controlled by the owner or operator of the proposed source in the same AQCR as the proposed source are in compliance 
banking. The permit applicant was required to obtain offsets from existing sources in the area sufficient to exceed the amount of emissions that would be produced by the new or modified source. ${ }^{20}$ The critical feature of offsets was that they were required to represent emission reductions beyond those required of the parent source under the SIP. ${ }^{30}$ Because these offsets were unanticipated, their use would not interfere with the scheduled attainment of NAAQS. In addition, something greater than a one-to-one exchange of offsetting reductions for usable offsets was necessary, so that the transaction would represent "reasonable progress." 31 Another limitation was that the offset could be applied only to the same type of air pollution: a reduction in sulfur-dioxide emissions, for example, could not offset a new emission of nitrogen dioxides. ${ }^{32}$ Therefore, if the locality of a proposed new plant was a nonattainment area for two or more pollutants, then intrapollutant offsets would have to be obtained for each.

The offsets could be produced in several ways. If an owner wished to expand his plant, he could install tighter controls on his existing operations, perhaps including use of innovative technology or controls so costly that they were not mandated by the SIP. Alternatively, the owner of the proposed source could pay the cost of taking extra pollution-control measures at a neighboring plant. In some cases, an applicant could purchase an existing facility and close it down. Smaller quantities of offsets could be generated by using less contaminating substances on jobs such as road paving or

with all applicable SIP requirements." Id. 55,529. Third, the required emission offsets must have provided for a "net air quality benefit" in the area. Id. This requirement essentially restricts the geographic origin of offsets because, for example, sulfur dioxide does not disperse well, reduction in its emission at one spot within a nonattainment area would not necessarily compensate for an increase in emissions when the new source is constructed some distance away. To provide air quality benefit, such offsetting reductions will most likely have to come from an existing plant very near the proposed source. In contrast, highly volatile contaminants such as hydrocarbons, which disperse easily, could be obtained from anywhere "in the broad vicinity" of the new source. See J. QuarLes, supra note 12, at 76. Finally, the 1976 ruling provided that construction was impermissible in any area for which an SIP had not been approved by EPA. 1976 Offset Ruling, supra at 55,529. All except the last condition were carried over into the 1979 Offset Ruling, supra note 7 , at 3,284 .

291976 Offset Ruling, supra note 4, at 55,529.

30 See text accompanying note 16 supra.

31 Thus, five tons of unrequired reduction might translate into four tons of bankable offset. Exactly what ratio would be applied was left to the individual states: "As long as the emission offset is greater than one-for-one, . . EPA does not intend to question a reviewing authority's judgment as to what constitutes reasonable progress." 1976 Offset Ruling, supra note 4, at 55,529-30.

32 Id. 55,529 . 
painting. Likewise, pollution could be abated through better maintenance, such as more frequent valve inspections. ${ }^{33}$

Congress expressly approved EPA's offset scheme when it amended the Clean Air Act in 1977.34 The task of administering the permit system and applying the agency's offset conditions fell to the states, ${ }^{35}$ but until their SIPs were revised, EPA's 1976 ruling was to remain in effect. ${ }^{36}$

\section{B. The No-Banking Provision}

EPA initially disposed of the banking issue, with which this Comment is principally concerned, in a summary fashion. The 1976 ruling stated, "Once an emission offset has been executed ...., there can be no leftover credit to 'bank' for additional new source growth in the future." ${ }^{37}$ This meant that any emission-offset arrangement had to involve contemporaneous reductions and construction and that emission reductions in excess of those required as offsets for a specific new source forever lost their value as offsets. Thus, for example, if existing source $A$ reduced its pollution by 150 units in order to offset new source $B$ 's emissions of only 100 units, fifty units of offset capacity would be lost if not immediately assigned to a specific use by another new or modified source. Such excessive reductions could occur when, for instance, estimations of offset availability proved inaccurate, or when technologies of scale allowed only larger than needed offsets. ${ }^{38}$

Although EPA defended its no-banking rule by suggesting that a pro-banking rule would be "inconsistent with a basic policy of the [Clean Air] Act" 39 and would create difficult "accounting problems," 40 the agency did not elaborate on this position. EPA seems to have been concerned primarily with the situation in which an existing source reduces emissions beyond SIP requirements but

33 See Comment, supra note 1 , at 580. 1977).

34 Note accompanying Clean Air Act $\$ 129$ (a)(1), 42 U.S.C. $\$ 7502$ (Supp. I

35 Id. $\$ 702$ (b) (6), 42 U.S.C. $\$ 7502(\mathrm{~b})(6)$ (Supp. I 1977).

36 Id. $\$ 129$ (a) (1), 42 U.S.C. $\$ 7502$ (Supp. I 1977 ).

3т 1976 Offset Ruling, supra note 4, at 55,529.

38 Pollution-abatement techniques tend to have a step-like function. Reductions cannot or tend not to be in discrete increments. It may, for example, be necessary to cut emissions by 100 tons in order to achieve a 50-ton reduction because it is not efficient to make a smaller reduction. See Memorandum from J. Fitzgerald to C. Wasserman (Nov. 15, 1977) (available at EPA Public Information Reference Unit, Washington, D.C.).

391976 Offset Ruling, supra note 4, at 55,526.

40 W. Barber \& D. Hawkins, "Banking" Under the Emission Offset Interpretative Ruling (internal EPA memorandum) (Nov. 8, 1977) (available at EPA Public Information Reference Unit, Washington, D.C.). 
then "sits on" the offsets until it might want to use them. To the extent that the offset policy was a response to the economic stagnation which private industry had accused environmentalists of aggravating, it seemed only proper to insist that such offsets be used immediately to stimulate jobs.11 Beyond consideration of this factor, EPA's initial evaluation of emission banking may have been fairly cursory.

\section{EPA Reverses Itself}

In the period following promulgation of the 1976 ruling, EPA received numerous comments on it-primarily from industry ${ }^{42}$-and spent considerable time reevaluating it. By the time the agency issued its revised ruling in 1979, it had completely reversed its position.43 The agency acknowledged that the "'no-banking' rule would have an adverse air-quality impact (at least in the short term) by discouraging early clean-up of sources" 44 beyond what was specifically required by the SIP. EPA realized that, without banking, sources would be inclined to maintain obsolete, highly polluting facilities simply to preserve potential emission reductions for use as future offsets. Alternatively, a source might delay adding pollutionabatement equipment to its facilities until it or some new source actually needed to use the offsets. These arguments had appeared frequently among the public comments received by EPA.45 Moreover, it had been suggested that the existence of offset inventories would assist industries in engaging in long-range planning and enable new-source applicants more easily to locate usable offsets for sale. ${ }^{48}$

In effect, banking provides incentives which would not necessarily generate more offsets in the long run ${ }^{47}$ but would encourage

41 Interview with D.K. Berry, EPA Office of Air Quality and Standards (Aug. 1979) (notes on file with the University of Pennsylvania Law Review).

42 See MCA Record, supra note 8: illustrative are the comments in the record from ARCO Chemical Co. (Oct. 17, 1978); Dow Chemical (Mar. 14, 1979); and Tenneco Chemicals (Mar. 6, 1979).

431979 Offset Ruling, supra note 7, at 3,280. In its preamble to the revision, EPA briefly cited the reasons for its original opposition: "[I]t was felt that banking would create a difficult accounting problem, probably would not result in any environmental benefit, and tended to dilute the potential benefits of the offset policy." Id.

44 Id.

45 See note 42 supra.

46 See J. Hoffman, Economic Advantages of Emissions Banking Systems (EPA Office of Planning and Management, No. 79-54.7) (undated).

47 Over a long period of time, pollution controls might be equally spurred by discouraging reliance on an assumption that offsets will be obtainable in the marketplace and forcing new-source applicants to initiate pollution-control measures at existing plants. 
more firms to produce them as quickly as possible. Without banking, only those firms contemplating imminent expansion or construction of new sources would be alert to possible conservation measures and motivated to invest in research for the development of better pollution controls. With banking, all existing sources can hold offsets for sale to the highest bidders, encouraging them to find untapped opportunities for emission abatement. Banking thus seems consistent with the "technology-forcing" strategy underlying the Glean Air Act. ${ }^{48}$

The consistency of banking with the Clean Air Act, however, is by no means a settled question. After all, Congress gave blanket approval to the 1976 offset ruling which had prohibited banking. ${ }^{49}$ The 1977 amendments to the Act provided, though, that the offset policy was to be followed "as may be modified by rule of the Administrator," 50 implying that EPA had authority to alter its stance on banking at its discretion. Moreover, the change to banking seems at first glance harmonious with Congress's own shift of policy toward accommodating the needs and concerns of industry. ${ }^{51}$ The 1977 amendments still require attainment of relatively stringent abatement standards, but Congress has retreated from favoring abatement at virtually any technological or economic cost ${ }^{52}$ to recognizing the need to encourage strengthening of the economy. ${ }^{53}$ To this end, Congress introduced slack and flexibility into the pollution-reduction program, principally through approval of the

48 For a close look at this strategy, see Note, Forcing Technology: The Clean Air Act Experience, 88 Y YLE L.J. 1713 (1979). One impediment to progress, according to the author, is the tendency of industries to concentrate too much on development of new-process technology, applicable only to new plants, and not enough on developing controls for installation at existing plants. Id. 1721 \& $n .42$. To the extent banking gives existing plants an incentive to overcontrol their emissions beyond SIP requirements, the new policy may correct this imbalance.

49 Note accompanying Clean Air Act $\$ 129(\mathrm{a}), 42$ U.S.C. $\$ 7502$ (Supp. I 1977). This section of the statute sets forth the SIP requirements for state programs; the note indicates that the 1976 ruling is to apply until the states comply. That ruling, however, never authorized banking. See text accompanying note 37 supra. 1977).

50 Note accompanying Clean Air Act $\$ 129(a), 42$ U.S.C. $\$ 7502$ (Supp. I

51 See note 5 supra \& accompanying text.

52 See, e.g., Note, Economic and Technological Feasibility Under the Clean Air Act Amendments of 1970, 51 Notre DaMe LAw. 849, 852-54 (1976); Note, Considerations of Technological and Economic Factors in Air Pollution Control, 44 U. CIN. L. REv. 573, 588-90 (1975).

53 H.R. REP. No. 294, 95th Cong., 1st Sess. 210, reprinted in [1977] U.S. CoDE CONG. \& AD. NEWS 1289. 
emission-offset provisions. Banking is simply another step in the same direction.

The 1979 offset ruling overstates the case, though, when it claims that banking was specifically endorsed by the 1977 amendments; indeed, the term does not appear anywhere in the statute. According to EPA, Congress modified the "no-banking provision" in the 1976 ruling "by allowing States to incorporate provisions for growth in SIP plans for non-attainment areas." 54 Although no citation is given, the allusion seems to be to section $173(\mathrm{l})(\mathrm{B}),{ }^{65}$ which the legislative history reveals was viewed by conferees as an alternative procedure to the emission-offset analysis."6 The "allowance for growth" scheme permits states to establish SIP limitations more rigorous than necessary to achieve national ambient air quality standards, resulting in a cushion for growth which the state can allocate to new sources "without case-by-case offset determinations." ${ }^{57}$ Such a scheme is clearly distinguishable from the one permitted by EPA's new ruling whereby individual firms voluntarily produce excess reductions and bank them in a state registry for their own future use or for sale to others at a profit.

The concept of emission offsets was endorsed by Congress in the alternative paragraph of section 173(1). Indeed, the 1979 offset ruling states that "[u]nder section $173(1)$ of the Act, emission reductions are compared to a 'reasonable further progress' goal, and reductions beyond the minimum requirement may be used to offset future growth." 58 Although the provision cited does establish

541979 Offset Ruling, supra note 7, at 3,280.

55 The section reads, in pertinent part:

The permit program required by section $7502(\mathrm{~b})(6)$ of this title shall provide that permits to construct and operate may be issued if-

(1) the permitting agency determines...

(B) that emissions of such pollutant resulting from the proposed new or modified major stationary source will not cause or contribute to emissions levels which exceed the allowance permitted for such pollutant for such area from new or modified major stationary sources.

Clean Air Act $\$ 173(1)(B), 42$ U.S.C. $\$ 7503(1)(B)$ (Supp. I 1977). See J. Quardes, supra note 12, at 67-68; Rosenberg \& Friedman, supra note 24 , at 554-55.

56 See H.R. Rep. No. 95-564, 95th Cong., 1st Sess. 157, reprinted in [1977] U.S. CODE CONG. \& AD. NEWS 1502, 1537.

57123 Cong. REc. S. 13702 (daily ed. Aug. 4, 1977) (remarks of Sen. Muskie). 581979 Offset Ruling, supra note 7 , at 3,280 . 
"reasonable further progress" as the standard for evaluating offsets, it nowhere says that reductions beyond the minimum SIP limits can be used to permit future growth. ${ }^{59}$ The ability in the first instance to make use of offsets does not necessarily imply the right to bank those offsets; at least, this is not self-evident. In short, EPA has read paragraph (A) of section $173(1)$, authorizing offsets, and paragraph (B), authorizing banking, as complementary despite their separation by the word "or." In a sense, Congress's willingness, in effect, to let the states bank offsets under paragraph (B) supports the inference that it saw nothing wrong with banking per se. If this view is taken, however, the same provision would seem to suggest Congress's unwillingness to confer blanket power on private sources to bank at will, reserving that power to environmental authorities instead.

EPA's 1979 offset ruling places no such restriction on the implementation of banking. Indeed, the ruling does little to outline exactly how a banking policy should function if a state chooses to adopt it.60 Although a state would become the "banker," it is unclear if this word is intended to connote ownership or merely supervision. In fact, no precise answer is given to the question of who will own the offsets produced in excess of SIP requirements; instead, this is a matter to be decided by each state, which is "free to govern ownership, use, sale, and commercial transactions in banked emission offsets as it sees fit." ${ }^{61}$ What little concrete guidance EPA offers certainly leaves open to the states the option of treating offsets as purely private property. ${ }^{62}$

59 Clean Air Act $\$ 173(1)(A), 42$ U.S.C. $\$ 7503$ (I)(A) (Supp. I 1977), reads in pertinent part:

The permit program... shall provide that permits to construct and operate may be issued if-

(1) the permitting agency determines that-

(A) by the time the source is to commence operation, total allowable emissions .... in the region ... [including those from the proposed source] will be sufficiently less than total emissions from existing sources allowed under the applicable implementation plan prior to the application for such permit ... so as to represent ... reasonable further progress.

60 Under the ruling, states are free to adopt banking, but are not required to do so. 1979 Offset Ruling, supra note 7, at 3,280.

$61 I d$.

62 "The reviewing authority should provide a registry to identify the person, private entity, or governmental authority that has the right to use or allocate the banked emission reductions, and to record any transfers of, or liens on, this right that the reviewing authority may allow." Id. 


\section{The Problem of Private Ownership}

The precise legal characteristics of emission offsets have only begun to be analyzed ${ }^{63}$ despite the important consequences which their legal classification has for the implementation of offset banking. Emission offsets fall into one of three possible categories. At one extreme, they can be considered the exclusive property of the parent source which produced them. Alternatively, at the other extreme, offsets can be treated as public property, even though private investments are usually responsible for their creation. Finally, offsets can be viewed not so much as physicial entities but rather as legal instruments, awarded to private investors in pollution control, which indicate the availability of certain amounts of air for private consumption subject, however, to terms and conditions set by the government.

\section{A. The Preference of Industry}

Most of the public comments received by EPA following promulgation of the pro-banking rule advocated making offsets the exclusive property of the parent source. ${ }^{64}$ The commentatorsprimarily industrial concerns-felt that it would be unfair to deprive a private company of ownership when it had spent money to produce the offset, and that to do so would eliminate the incentive to produce offsets, thus defeating the purpose of the ruling. Offset banking, it was argued, should operate in a manner akin to the banking of any other asset. For example, the parent source would be able to open an offset "account" with a banking authority (probably a state agency), deposit offsets into the account, and withdraw offsets as needed. ${ }^{65}$ Regardless of the precise contours of such a system, its salient feature would be that ownership itself would confer rights to use and alienate freely one's offsets: it would grant, in essence, a right to pollute equivalent to the size of the offset. That right, moreover, implies the right to retain the offset for an indefinite period before use. ${ }^{68}$

${ }^{63}$ An early survey of these issues appears in Comment, supra note 1.

64 See MCA Record, supra note 8: in addition to the comments cited in note 42 supra, see also those from Independent Liquid Terminals Ass'n (ILTA) (Mar. 19,1979 ) and the American Iron and Steel Institute (Mar. 15, 1979).

65 See, e.g., MCA Record, supra note 8: comment from Independent Liquid Terminals Ass'n (Mar. 19, 1979), going so far as to suggest that emission "savers" should have a right to "interest" on their banked offsets which are "loaned" to new sources. Such a scheme would surely undermine any long-term remedial purposes of the Clean Air Act.

66 It should be noted that the market for offsets would not diminish once compliance with NAAQS is achieved; any new source to locate in the area would cause renewed violations unless it is able to offset its emissions. 
Serious allocation problems may arise, however, from private ownership, threatening nonattainment areas with economic stagnation. Once banking removes the need for production and sale to be contemporaneous, offset markets are subject to the dangers of undue concentration and prolonged hoarding of offsets. Without limits on how large a share of the regional offset supply any one source can possess, market abuses may develop. Likewise, without limits on how long offsets can be banked, several sources may each "hoard" their offsets indefinitely. ${ }^{67}$ In either case, the effect is the same: new sources are lost for lack of needed offsets. In light of the fundamental purpose of the offset policy-to allow industrial growth despite stringent air-quality standards ${ }^{68}$-such market failures should be deemed critical. Yet, perhaps because the drafters of the Clean Air Act never contemplated offset banking and the full-blown market it might spawn, ${ }^{69}$ that statute confines its regulation to situations in which a source seeks a permit to construct; transactions between sources involving offsets are ignored. The discussion which follows attempts to show that the problems of hoarding and anticompetitive behavior, though not totally beyond the reach of existing laws, are nonetheless acute when offsets are privately owned. The remainder of this Comment will suggest that the problems of "how much" and "how long" may be more satisfactorily addressed if alternative concepts of ownership are applied.

\section{B. The Problem of Unlimited Duration}

\section{The Potential for Speculation}

If an existing source can legitimately hold its unused offsets without limit, then the productive potential of the offsets is lost. On the other hand, limited duration provides the incentive for a source to continue its pollution-reduction programs. Knowing that

67 See text accompanying notes 83-91 infra.

68 See H.R. REP. No. 294, 95th Cong., 1st Sess. 208-10, reprinted in [1977] U.S. CODE CONG. \& AD. NEws 1287-89:

On the one hand, protection of the public health remains the predominant goal of the Clean Air Act. . . .

On the other hand, a complete prohibition on new growth or expansion in nonattainment regions would pose very serious problems.

. . [I]n areas of particularly high unemployment complete restriction of growth or expansion . . . might exaggerate unemployment or at least hinder reemployment efforts. . . .

In order to reconcile these conflicting concerns, the committee adopted section 117 [the offset provisions] of the bill.

69 See notes $49-50$ supra \& accompanying text. 
its offsets may expire, a source must continue to look for untapped opportunities for emission reduction if it wishes to maintain a steady inventory of offsets.

Allowing offsets to be banked indefinitely may encourage the development of a speculative offset market. Brokers or companies could buy up offsets and hold them in the hope that their value would increase. If industrial expansion proceeds at a rate faster than the improvement in pollution-abatement technology, ${ }^{70}$ or if, as one commentator suggests, "there are only so many emission reductions that can be squeezed out of a given area," 71 then enormous profits can be realized from such nonproductive activity. ${ }^{72}$ By the same token, given such probable scarcity, a cautious business with visions of future expansion may jealously hold onto offsets not for speculation but for fear that none will be available when it wants them. Thus, it may be desirable to force parent sources either to put their reductions to productive uses or to sell them within a certain period of time.

\section{Problems of Confiscation Under a Private-Property Model}

The Clean Air Act casts a cloud over this prospect of unlimited speculation in offsets, but the cloud derives from the ambiguity of the Act's provisions rather than from any direct, carefully conceived regulation.

70 Another commentator has suggested that, although the technology-forcing strategy of the Clean Air Act generally works, several factors inherent in the law may actually impede the development of better technology. See Note, supra note 48, at 1727-28. If this analysis is correct, it reinforces the assumption made throughout this Comment that pollution abatement is unlikely to undergo vast improvement, and thus offsets will remain a scarce, valuable resource. But see note 48 supra.

71 Comment, supra note 1 , at 598.

72 At least one state has structured its proposed banking scheme specifically to exclude "middlemen" from offset trading to try to forestall the likelihood of speculative investment. Pennsylvania's draft offset policy states: "Only emission offsets that have been transferred directly from an existing source to the proposed source will be recognized under this section. Transfer of emission offsets through intermediate parties cannot be applied to meet the requirements of this section." PA. Cone tit. 25, pt. I, $\$ 127.66$ (c) (1979). The drafters "particularly wishe[d] to avoid a situation where . . . a third party buys emission offsets for financial speculation and holds them indefinitely, thereby prohibiting a new source from locating in an area and providing employment and other economic benefits to the area." Bureau of Air Quality Control, Dep't of Environmental Resources, Commonwealth of Pennsylvania, Proposed Revisions to Implementation Plans: Summary of Comments and Responses 5 (June 12, 1979).

By eliminating the broker-dealer, such measures may inhibit, but not necessarily foreclose, speculative hoarding; producers of offsets would still have incentives to hold them for future sale or use. The proposals suggested in part IV may curb abuses more effectively without per se excluding successive offset transactions. See text accompanying notes 103-18 infra. 
Because the Act does not explicitly authorize banking of offsets, it is not surprising that Congress expressed no opinion about whether offsets can be held indefinitely and, if so, how they are affected by revisions in the SIP. Under section $173(\mathrm{I})(\mathrm{A})$ of the Act, however, the amount of emission reduction that can be used to offset a proposed new source is calculated by using the SIP baseline in effect when the application for a permit is made ${ }^{73}$ rather than when the offsets are created. Tightening the SIP levels applicable to a firm thus has a confiscatory effect on any offsets not yet used in a permit application. ${ }^{74}$ Still, such SIP revisions are clearly authorized by statute ${ }^{75}$ and may be necessary as compliance deadlines draw nearer. ${ }^{76}$

As a result, the statute invites suspicion that a firm's banked reductions may be "confiscated," thus destroying the incentive for current conservation that banking was supposed to provide. Proponents of banking have stressed that assurances against confiscation are critical to the program's success, ${ }^{77}$ and this need may be given as a justification for granting offsets the status of vested property rights. In fact, however, it is doubtful that treating offsets as private property would necessarily dispose of the confiscation problem or allay investors' fears. Although the law of takings resists simple analysis, constitutional doctrine permits the confiscatory effects of government regulation when necessary to protect public health under the police power. ${ }^{78}$ Tightening SIP baselines to adjust for

73 Clean Air Act $\$ 173(1)(A), 42$ U.S.C. $\$ 7503(1)$ (A) (Supp. I 1977). See note 59 supra.

${ }^{74}$ To illustrate, suppose Firm $X$ reduces its emissions by 10 tons per year below the level required of it by the SIP in effect at that time. The state is using a 1.1:I offset ratio, see note 31 supra, so the firm gets to bank 9 tons. In order to compensate for unforeseen deterioration in air quality and enable the area still to attain NAAQS by the statutory deadline, the state finds it necessary to revise SIP quotas downward so that $X$ 's allowable emissions are reduced by 2 tons per year. When $X$ or its transferee applies for a permit, it would then receive credit for only 7 tons per year, rather than 9 , because offsets are allowed only for excess reductions, and the stricter baseline has, in effect, erased part of the excess. 1977).

75 Clean Air Act $\$ 110(a)(2)(H), 42$ U.S.C. $\$ 7410(a)(2)(H)$ (Supp. I

76 State environmental authorities might have to adjust SIP quotas to compensate for exemptions granted to existing sources, or to "make room" for a new industrial source which local authorities have lured to their region. See Rosenberg \& Friedman, supra note 24 , at 532-33 \& 540-41. Revisions might also be necessitated by inaccurate predictions or from unanticipated increases in pollution from new non-major sources not subject to the permit-requirement process and, therefore, not within the state agency's power to control.

77 EPA Office of Planntag \& Management, Plannang for Clean Adr \& a Strong Economy 9 (1979) [hereinafter cited as PLANNING]; see J. HIoffman, supra note 46 , at 6 .

78 Despite claims by owners that the economic value of their land had been totally destroyed, noxious uses of property were not protected from confiscation in 
unanticipated increases in pollution would thereby seem a legitimate exercise of police power. At most, treating offsets as private property might assure owners "equal protection"; 79 that is, emissions from existing sources would have to be reduced by the same percentage at which banked offsets are discounted, equalizing the impact on bankers and non-bankers. Conceivably, too, offset holders might further argue that offsets, unlike land, have only one use and that, therefore, deprivation comes within the category of "total destructions" for which compensation may be allowed.80

Allowing notions of private-property rights to plant such obstacles in the path of SIP revisions would seriously impair the statutory powers of state environmental authorities. Creators and purchasers of offsets must be put on notice that banked reductions may be discounted. The law should, however, attempt to minimize the uncertainty created in the offset market by the possibility of confiscation. To the extent SIP baselines can change at any time, businesses may find it too risky to produce and hold onto offsets, and the potential benefits to the economy of a banking program will not be realized. ${ }^{81}$ Treating offsets as private property does not, as we have seen, solve this problem. ${ }^{82}$

\section{Antitrust Problems}

The discussion of hoarding in the previous section assumed a competitive market in which offsets are held by several sources. Because of the probable scarcity of offsets, however, they may be

Goldblatt v. Town of Hempstead, 369 U.S. 590 (1962) (sand- and gravel-mining operation prohibited by zoning amendment); Hadacheck v. Sebastian, 239 U.S. 394 (1915) (brickyard closed without compensation because it endangered health of city population growing around it). See generally L. Trme, AMrerican ConstrioTIONAT LAW 459-63 (1978).

79 On the "equal protection dimensions of compensation law," see Sax, Takings, Private Property and Public Rights, 81 YALE L.J. 149, 169-71 (1971).

80 See L. TruBE, supra note 78, at 460; cf. Mandelker \& Sherry, Emission Quota Strategies as an Air Pollution Control Technique, 5 Econocy L.Q. 401, 418-19 (1976) (restraints imposed on the private use of land by emissions quotas may be so total as to constitute a "taking" of the land).

81 Consider, for example, the potential disincentive to offset creation and banking contained in the following section of Pennsylvania's new offset procedure: "In the event new regulations are established under this title, emission offsets from sources covered by the new regulations will not be allowed in the consideration of a plan approval application from the date the Environmental Quality Board adopts such new regulations." PA. CoDE tit. 25, pt. I, \$127.66(b) (1979). The plain language of the rule seems to suggest the exasure of all accumulated offsets in the event of any change in the regulations covering the parent source, though it is difficult to see why such possibly drastic consequences would be necessary in every case.

82 For a proposed solution involving a grant of temporary rights to offsets, see text accompanying notes $112-19$ infra. 
collected by a single source or cartel of sources, in which case various antitrust considerations will arise. ${ }^{83}$ The geographic constraints on the relevant market and the requirement that offset exchanges be intrapollutant ${ }^{84}$ further limits the number of potential sellers in any one nonattainment area. Because industrial growth in such areas is contingent upon finding sufficient offsets to meet permit conditions, much market power devolves upon those firms able to gain possession of substantial offsets. The potential effect on prices could be undesirable. Moreover, in areas with a concentration of similar sources, such as auto plants or steel mills, there could even exist the possibility of collusive behavior among competitors to benefit themselves and disadvantage an excluded competitor.

A truly free market in emission offsets may, therefore, have to rely significantly on effective enforcement of antitrust laws to ensure competition. A look at specific scenarios illustrates the extent to which antitrust analysis can help resolve the problems.

Assume that a particular firm is the sole major source of a certain pollutant within a given nonattainment area and is able to reduce its emissions such that a significant volume of offsets is produced. The firm thus enjoys a virtual monopoly in that category of pollutant. This position as such almost certainly violates no law: monopoly power resulting from the exclusive, fortuitous ownership of a scarce resource is not illegal. ${ }^{85}$ It would, in fact, be contrary to the purposes of the banking policy to punish the firm for having produced so many offsets. Under circumstances in which the monopoly is a natural and legal consequence, antitrust law by itself, divorced from public-utility regulation, is relatively powerless to control prices. ${ }^{86}$ Such a monopolist is not, however, in a position to discriminate unfairly among purchasers of a scarce resource and thus effectively admit some firms, but not others, into a nonattainment area. ${ }^{87}$

83 See J. Hoffman, supra note 46 , at 5.

84 See text accompanying note 32 supra.

85 See United States v. Grinnell Corp., 384 U.S. 563, 570-71 (1966); United States v. Aluminum Co. of America, 148 F.2d 416, 429-30 (2d Cir. 1945) (dictum); L. Sullivan, HaNdBook OF THE Law OF ANTITRUSt $\$ \$ 33-39$ (1977).

86 See id. $\$ 47(\mathrm{~b})$.

87 For instance, in United States v. Terminal R.R. Ass'n of St. Louis, 224 U.S. 383 (1912), the Supreme Court found illegal under the Sherman Act, 15 U.S.C. $\$ \S 1-7$ (1976), an arrangement whereby the only railroad bridge across the Mississippi River at St. Louis, among other properties, had come under the ownership of a single company, and those needing to use the bridge were given access on a discriminatory basis so as to restrain competition among affected rail carriers. See also 
When market dominance in offsets arises, not naturally by reduction of one's own emissions, but rather by purchase of others' offsets beyond one's reasonably foreseeable needs, then antitrust law may be able to cure the resulting anticompetitive effects on offset prices and entry of competing firms. Proof of specific intent to monopolize may not be necessary in every case..$^{88}$

Finally, consider situations in which two or more sources might unite in their control of offsets. The formation of a price-fixing cartel would clearly be per se illegal. ${ }^{89}$ Also, if the sources jointly refuse to sell to a purchaser in order to restrain competition, they would likely be subject to suit for illegal boycotting. ${ }^{90}$ Whether the law would permit a joint agency for selling offsets, whereby the holders in an area appoint an exclusive agent to sell their offsets for them, would probably depend very much on the circumstances of each case. ${ }^{91}$

As the preceding examples suggest, antitrust law would provide remedies for blatantly anticompetitive conduct by offset bankers. The monopolistic effects of a self-generated abundance of offsets may not, however, be as easily remedied. Moreover, it is quite possible that conduct similar to the extreme examples discussed, but

Otter Tail Power Co. v. United States, 410 U.S. 366 (1973); Gamco, Inc. v. Providence Fruit \& Produce Bldg., Inc., 194 F.2d 484 (1st Cir.), cert. denied, 344 U.S. 817 (1952).

88 Having deliberately achieved control over all the offsets in an AQCR, a firm may be found to have illegally monopolized, "however innocently it otherwise proceed[s]," just by virtue of its ultimate control over the market. United States v. Aluminum Co. of America, 148 F.2d 416, 432 (2d Cir. 1945). If it can be shown that the firm intends to gain monopoly power and exclude competitors from the area, then the firm's acquisition activity would clearly fall under the proscription against "attempt[s] to monopolize" in section 2 of the Sherman Act. 15 U.S.C. $\$ 2$ (1976). See United States v. United Shoe Mach. Corp., 110 F. Supp. 295, 349 (D. Mass. 1953). In addition, decisions punishing speculators who corner the market in commodities so as to reap the profits from inflated prices should be equally applicable to dealers speculating in offsets. Cf. Peto v. Howell, 101 F.2d 353 (7th Cir. 1938) (corn futures).

s9 See, e.g., United States v. Socony-Vacuum Oil Co., 310 U.S. 150 (1940); United States v. Trenton Potteries Co., 273 U.S. 392 (1927).

90 See, e.g., United States v. General Motors Corp., 384 U.S. 127 (1966); Paramount Famous Lasky Corp. v. United States, 282 U.S. 30 (1930).

91 See generally L. SuLLIVAN, supra note 85, at $\$ 104$. For instance, in Appalachian Coals, Inc. v. United States, 288 U.S. 344 (1933), a group of coal producers, controlling about 73\% of the output in their area, created a joint agency for selling their coal. Even though the agency went so far as to set prices for the coal sold, the Court applied a "rule of reason" and found that, given the very unstable conditions of the market and the industry, the arrangement was not an unreasonable restraint of trade. By way of contrast, when a group of excelsior producers made an exclusive sales-agency agreement that, among other things, set the price at which their product was sold, the court held the combination per se illegal under the Sherman Act. Virginia Excelsior Mills, Inc. v. FTC, 256 F.2d 538 (4th Cir. 1958). 
with fewer clear indicia of anticompetitive purpose or effect, would be not only harder to detect but also less amenable to antitrust prosecution. The sheer length and complexity of much antitrust litigation ${ }^{22}$ could negate the realistic value of the remedy. Furthermore, antitrust law neglects interests unconnected with competitive considerations. Other pressing public interests, such as employment or tax-base maximization, may dictate that even natural monopolies in offsets be compelled to divest their holdings or have their selling prices approved, so that offsets may be converted to productive use. In short, some type of regulatory framework, removing offsets from solely private ownership, may be needed if society is to reap the full benefits of an offset-banking policy instead of just preventing the blatant abuses.

\section{The Public-Property Alternative}

One alternative to the vested-property-rights theory is to require that all excess reductions which a parent source creates, but cannot presently use or sell, revert automatically to the public domain. This scheme would remove bankable offsets from private hands altogether and give environmental authorities ultimate power over their allocation..$^{33}$ Although this arrangement might eliminate many of the problems associated with private ownership, it would also significantly undermine the private incentives to overcontrol which banking was designed to support. ${ }^{94}$ If polluting sources are unable to profit from (or at least recover the cost of) pollution abatement beyond that required by the SIP, they would produce offsets far more slowly, or not at all. The stimulus to cut emissions would have to come from the SIP in the form of tighter restrictions de-

92 See, e.g., P. Areeda \& D. Turner, 2 ANTrTrust Law $\int 318$ (1978) ("Indeed, the antitrust case may involve so many issues, documents, witnesses, and lawyers as to defy comprehension."). See also L. Sulrrvar, supra note 85 , at $\$ 244$.

93 In fact, some staffers at EPA apparently espoused this position during the agency's internal policymaking discussion prior to promulgation of the original 1976 Offset Ruling:

We most strongly object to any language that implies that tradeoffs [offsets] may be a "marketable" or "bankable" right. The policy must make it absolutely clear that what is involved is a right of the permitting agency to adjust the mix of emissions limitations to make room for a new source, rather than any right of a source to pollute up to SIP levels. We object to any language which explicitly sanctions the creation of a free market for buying and selling the right to pollute, even if the creation of such a market is left to the discretion of the reviewing agency.

Memorandum from S. Legro, Enforcement Division, to EPA Deputy Director (Dec. 1,1976 ) (emphasis added), included in MCA Record, supra note 8 . Needless to say, EPA ultimately ignored this advice by approving both the banking and marketing of emission offsets.

94 See text accompanying notes $44 \& 45$ supra. 
signed to reduce pollution below the federally mandated standards, creating a cushion for growth which the state might then allocate to applicants at its discretion.

Tightening the SIP would be perhaps even more consistent with the Clean Air Act Amendments of $1977^{95}$ than the emissionoffset banking introduced by EPA. ${ }^{96}$ It would correspond to one of the two alternative procedures Congress granted the states for determining whether new growth would be permitted in a nonattainment area. Indeed, section $173(1)(B)$ of the Act, authorizing states to include an "allowance for growth" in their SIPs, envisions public ownership and government allocation of pollution rights. ${ }^{97}$ So, too, does the provision for new-source review in attainment areas under the Prevention of Significant Deterioration program, which charges EPA and local governments with responsibility for keeping already clean air clean by carefully distributing available growth increments to worthy applicants. ${ }^{98}$ Although skeptics of the "allowance for growth" procedure in nonattainment areas point to the difficulty of mandating SIP requirements tighter than are necessary to meet the national ambient air quality standards, ${ }^{90}$ it should be apparent that the obstacles are more political than technological. Even the offset program assumes that untapped opportunities exist for further emission reduction beyond that required for attainment; otherwise, the only offsets that could be created would derive from plant shutdowns and curtailments.

A more basic objection to the "allowance for growth" scheme is one directed at SIPs in general. One commentator has argued that setting emission limits on source categories merely encourages

95 Pub. L. No. 95-95, 91 Stat. 712 (1977) (current version at 42 U.S.C. $\$ \$ 7401-7626$ (Supp. I 1977)).

96 See text accompanying notes 54-59 supra.

97 The subsection reads:

The permit program required by section $7502(b)(6)$ of this title shall provide that permits to construct and operate may be issued if-

(1) the permitting agency determines...

(B) that emissions of such pollutant resulting from the proposed new or modified major stationary source will not cause or contribute to emissions levels which exceed the allowance permitted for such pollutant for such area from new or modified major stationary sources.

Clean Air Act $\$ 173(1)(B), 42$ U.S.C. $\$ 7503$ (1)(B) (Supp. I 1977). See J. QUARLES, stpra note 12, at 67-68; Rosenberg \& Friedman, supra note 24, at 554-55. 98 See Clean Air Act $\$ \$ 160-169,42$ U.S.C. $\$ \$ 7470-7479$ (Supp. I 1977); J. QUARLES, supra note 12, at 25-27; Raffle, supra note 7, at 47-48; Comment, Increment Allocation Under Prevention of Significant Deterioration: How to Decide Who Is Allowed to Pollute, 74 Nw. U. L. Rev. 937 (1980).

99 See J. QuaruEs, supra note 12, at 68; Rosenberg \& Friedman, supra note 24 , at 555 . 
palliative solutions and short-run fuel conversions rather than technological innovation and truly long-term solutions. ${ }^{100}$ Tightening SIPs might simply mean more of the same. One of the virtues of banking is that it furnishes a perpetual incentive to reduce emissions, an incentive which will not disappear once a certain required level is reached.

The more fundamental objection to the procedure contained in section $173(1)(B)$, or any prescription for government ownership and assignment of offsets, is that the optimal allocation of such offsets can be best accomplished by private-market forces rather than central planners. ${ }^{101}$ If the sum a potential user would pay is the measure of the value to it or of the productive use it can make of a resource, then the sale of offsets to the highest bidder will arguably reflect their most productive use. ${ }^{102}$ Meanwhile, the increasing price of purchasing offsets on the open market will encourage firms which have met SIP requirements to supply as many reductions as technology will permit and at the same time motivate sources that have not yet reached SIP targets to reduce their needs for offsets through conservation.

Thus, although local governments may want to examine the public-ownership route (specifically the statutory scheme creating "allowance for growth" in their SIPs, authorized by Congress in section $173(\mathrm{l})(\mathrm{B})$ of the Clean Air Act), this option, like private banking of offsets, has drawbacks. Moreover, the political costs of tightening SIPs make it a stark choice. Indeed, dissatisfaction with both the private- and public-ownership alternatives prompts a further search for options which would retain the advantages of price allocation and the conservation incentives which characterize private banking without totally sacrificing government's ability to curb market abuse and control offset use when required by public necessity. The final section of this Comment proposes a series of such intermediate solutions.

100 See Note, supra note 48 , at 1725-28.

101 See, e.g., R. POSNER, EcoNomic ANal.ysis of LAw $\$ 1.2$ (2d ed. 1977) ("Forced exchanges with an after-the-fact determination by the legal system as to whether the exchanges increased or reduced efficiency constitute a less efficient mechanism for the allocation of resources than market transactions-where market transactions are feasible.").

It is noteworthy that the Council on Wage and Price Stability has urged that a "complete market approach" be taken to emission rights. See Comment, supra note 1, at 595 n.110 (citing Easton \& O'Donnell, The Clean Air Act Amendments of 1977: Refining the National Pollution Control Strategy, $27 \mathrm{~J}$. ArR Pollution Cont. A. 943, 947 (1977)).

102 See T. Morgan, Cases and Materials on Economic Regulation of BusIness 118 (1976). 


\section{Proposed Solutions}

As discussed earlier ${ }^{103}$ the consequences of vesting absolute property rights in offsets are chiefly the risk of monopolistic behavior and the specter of offset shortages aggravated by offset holders' unwillingness to sell. The former may be difficult to police and the latter may not be culpable. Cautious businesses without current plans to expand may nonetheless be reluctant to yield offsets with the risk of being unable to repurchase them if later needed. Other firms may simply prefer to speculate and hold out for a higher price. Although in conventional markets such holdouts are usually a stimulus to new competition, the finite supply of offsets weakens this safeguard. In any case, the lack of sellers means needed source expansion or construction in a nonattainment area may have to be foregone. The challenge, therefore, is to protect the public interest in having valuable emission reductions put to productive use, without excessive government supervision of offset trading.

\section{A. State Acquisition of Offsets}

One possibility is for public authorities to become the sole purchaser of reductions, thereby discouraging brokers and speculators in the offset market. A public agency could then auction the offsets or, in special circumstances, divert them to projects which will particularly increase local employment and tax base. ${ }^{104}$ The problem with this solution, aside from the expense to the taxpayer, is that the public authority would then have an economic stake in maintaining SIP limits at their existing levels: reducing them would, in effect, erase the government's investment in marketable offsets. In a more philosophical vein, the cost of emission abatement should properly be borne by the sources themselves, not the taxpayer, in exchange for having placed the "externalities" of pollution on the public.

Adopting EPA's banking scheme, but with a tax in kind imposed on reductions when created, might be a better strategy for building a store of publicly held offsets. ${ }^{105}$ Such an assessment would not necessarily add an administrative step to the banking process. The levy could be made simply by setting the offset ratio

103 See text accompanying notes 70-72 \& 83-84 supra.

104 Compare the suggestion in EPA's 1979 offset ruling that "[a] State or community which desires that a source locate in its area may commit to reducing emissions from existing sources... to sufficiently outweigh the impact of the new source and thus open the way for the new source." 1979 Offset Ruling, supra note 7 , at 3,285 .

105 See Planning, supra note 77, at 24. 
-that is, the ratio of reductions to new emissions-at a level which would not only ensure "reasonable further progress" (as currently required by section $173(1)(A)$ of the Clean Air Act) ${ }^{106}$ but also create "an allowance for growth" (as envisioned by section 173 (1)(B)). ${ }^{107}$

In effect, this proposal represents a hybridization of the two alternate schemes authorized by Congress. The current EPA ruling interprets "reasonable further progress" as requiring that an emission trade-off yield a better than one-for-one improvement. ${ }^{108}$ So, for example, a SIP could stipulate that the ratio of actual emission reductions to new emissions must be at least 1.1:1 for certain pollutants. To create ten tons per year of bankable offsets, then, a source in that area must reduce its emissions by eleven tons per year. Because states have substantial discretion in setting the applicable ratio, ${ }^{109}$ the appropriate authority could instead apply a 1.3:1 ratio, thus requiring an operator to exchange thirteen tons of reduction for ten tons of offset, enabling the state to set aside two tons of emissions in a publicly owned bank account. Using such reserves, the local authority could undercut high market prices and thereby curb speculation. The fund could also be made available to new industries as an incentive to settle in the area. ${ }^{110}$

\section{B. The Patent Model}

Another fruitful approach is to consider other types of property rights recognized by law which combine incidents of both public and private ownership. For example, patents are designed in part to encourage inventions by granting a temporary monopoly to the inventor. ${ }^{111}$ Analogizing the creation of an offset to an invention, government authorities might grant to the parent source a patentlike right to the exclusive use of its offsets ${ }^{112}$ for a certain period of years, ${ }^{113}$ after which any remainder of unused offsets would revert

100 Clean Air Act $\$ 173(1)(A), 42$ U.S.C. $\$ 7503(1)(A)$ (Supp. I 1977).

107 Id. $\$ 173$ (1) (B), 42 U.S.C. $\$ 7503$ (1)(B) (Supp. I 1977).

1081979 Offset Ruling, supra note 7, at 3,285; see J. QuarLEs, supra note 12, at 74 . at 74 .

1091979 Offset Ruling, supra note 7, at 3,285; see J. QuarLes, supra note 12,

110 See note 104 supra.

111 E.g., P. AREEDA, ANTrTrust ANALysis 425-29 (2d ed. 1974).

112 For the structure of the patent system, see the patent statute itself, 35 U.S.C. $\$ \$ 100-293$ (1976 \& Supp. I 1977).

113 Patents are granted for a period of seventeen years. 35 U.S.C. $\$ 154$ (1976). Pennsylvania has, in effect, adopted the patent model for its banking system. Its new regulations provide that banked offsets "may only be used as offset credit by the applicant in a plan approval application filed within a period of five years" after their creation. PA. CoDE tit. 25, pt. I, $\$ 127.67$ (a) (1979). 
to the public domain. Such a system would permit the "patentee" to assign freely its unused offsets to another source ${ }^{114}$ and perhaps return a profit on its original pollution-cutting investment. Private incentives to overcontrol would be preserved and market forces allowed to operate, while at the same time the eventual expiration of the "patent" would exert pressure on the parent source to use or dispose of the offset productively within a reasonable amount of time, thus averting the economic stagnation that may exist if parent sources bank their offsets indefinitely. Moreover, limited duration promotes the technology-forcing strategy underlying the Clean Air Act ${ }^{115}$ by assuring that sources will be motivated to continue the search for pollution-cutting measures.

The patent model is not, however, foolproof. The grant of an absolute property right in offsets for a term of years does not preclude anticompetitive behavior by firms which might discriminate unfairly among customers or at least obtain short-term monopoly power by stockpiling most of the available offsets in a local market. ${ }^{116}$ Correction of such abuses would depend, as it does in the patent area, on the enforcement of antitrust laws, ${ }^{117}$ with all the accompanying uncertainties and expenses. ${ }^{118}$ From the viewpoint of a source operator, on the other hand, the possibility of unused offsets expiring may temper its willingness to produce current emission reductions unless a specific need or buyer for them is antici-

114 Cf. 35 U.S.C. $\$ 261$ (1976) (patent statute).

115 See Note, supra note 48.

116 Frustration at perceived abuses and maldistribution in the patent system have sometimes generated government attention and suggestions for reform. One such initiative proposed:

In order to eliminate the use of patents in ways inimical to the public policy inherent in the patent laws, as well as that of the antitrust laws, we recommend that the Congress enact legislation which will require that any future patent is to be available for use by anyone who may desire its use and who is willing to pay a fair price for the privilege. Machinery, either judicial or administrative, should be set up to determine whether the royalty demanded by the patentee may fairly be said to represent reasonable compensation or is intended to set a prohibitive price for such use.

Final Report and Recommendation of the Temporary Econ. Comm'n., S. Doc. No. 35, 77th Cong., 1st Sess. 36 (1941), quoted in L. Scriwartz \& J. FlynN, ANTITRUST AND Regulatory ALternnatives 1226 (5th ed. 1977).

It is worth noting, too, that the drafters of the Clean Air Act Amendments of 1970 specifically considered the potentially harmful impact of a patent system on its technology-forcing strategy and determined that an exception to the patent laws was required. Provision was made for compulsory licensing of patents on pollutioncontrol devices, despite the effect this had of removing incentives to invent such devices. See Clean Air Act $\$ 308,42$ U.S.C. $\$ 7608$ (Supp. I 1977).

117 See L. SulrIVAN, supra note 85, at $\$ 179$.

118 See note 92 supra \& accompanying text. 
pated in the foreseeable future. To some extent, then, the incentive for early pollution reduction, which the banking policy was designed to instill, ${ }^{119}$ would be undermined.

\section{The License Model}

Another legal analogue, even more promising than patents, is licensing. Rather than vesting any property right in the holder, a license is merely a grant of permission "to do a thing which the licensor could prevent." ${ }^{120}$ As such, conditions on its use may be attached and failure to comply with them can be punished by revocation. ${ }^{121}$ By limiting the duration of a license to a fixed period while holding open the possibility of successive renewals, the interests of the regulator and the operator may, as much as possible, be balanced.

The most conspicuous example of large-scale government licensing is broadcasting, in which the Federal Communications Commission (FCC) exercises exclusive jurisdiction over the licensing of radio and television operators. ${ }^{122}$ The scarcity of a valuable resource-available air frequencies-and the need to ensure that they were used responsibly persuaded Congress not to grant property rights to broadcasters despite their enormous private capital investment, but instead to issue licenses for short, three-year terms. ${ }^{123}$ The Federal Communications Act of 1934 obligates the FCC to ensure that, in extending licenses to broadcasters, the "public convenience, interest, or necessity will be served." ${ }^{124}$ Although in practice this duty may be paid only lip service ${ }^{125}$ and does not

119 See text accompanying notes 44-48 supra.

120 Black's Law Dictionary 829 (5th ed. 1979) (citing Western Elec. Co. v. Pacent Reproducer Corp., 42 F.2d 116, 118 (2d Cir. 1930)).

121 For an example of such conditions and penalties in the federal communications laws, see 47 U.S.C. $\$ \$ 308(f), 312$ (1976).

122 As its illustration of nonprice allocation of inherently scarce resources, one general casebook considers FCC licensing in depth. See T. MorGAN, supra note 102 , at 119-52 (1976).

123 Section 301 of the Federal Communications Act of 1934 reads:

It is the purpose of this chapter . . . to maintain the control of the United States over all the channels of interstate and foreign radio transmission; and to provide for the use of such channels, but not the ownership thereof, by persons for limited periods of time, under licenses granted by Federal authority, and no such license shall be construed to create any right, beyond the terms, conditions, and periods of the license.

47 U.S.C. $\$ 301$ (1976).

124 Id. $\S 307$ (a).

125 See generally B. Cole \& M. Oettinger, Retuctant Regurators: The FCC AND THE BROADCAST AUdIENCE 134, 177 (1978). 
preclude operators from making profits by use or sale of the license, at least the legal principle has been established that no property right inheres in a broadcast license, ${ }^{126}$ and that it may be closely regulated ${ }^{127}$ or even revoked, at least for "good cause." 128

Communications law thus provides a good example of an accommodation between the need to make economic use of a scarce valuable resource and the need to protect the public interest in that resource. Because of the great value placed on clean air, the emission-offset policy requires this type of accommodation.

Under such a system, when a source reduces its pollution below the required SIP level, the appropriate state agency would issue it a license to offset an almost equivalent increase in emissions caused by new construction or expansion of facilities. The license would entitle the holder itself to consume these offsets or sell them for profit to another source within a fixed term of years, ${ }^{120}$ subject to revocation at any time for abuse inconsistent with the public interest. During this time the state would be restrained from reducing the "amount" of offsets by revising the SIP baseline, ${ }^{130}$ so both buyers and sellers could deal with greater certainty and foresight. The producer of offsets who is unable to use or sell the privilege within the allotted time could seek to have the privilege renewed for another term, but, at this stage, the appropriate state agency could exercise its statutory authority ${ }^{131}$ to revise SIP limits downward (thereby erasing the offsets) and adjust the mix of allowable pollutants, if necessary, to meet unforeseen delays in attainment. In this way a compromise is struck between business's desire for predictable SIP baselines and the public's interest in retaining some control over SIP to meet future contingencies. ${ }^{132}$

Advocates of a more active governmental role in offset allocation might wish to give states even more flexibility at the renewal stage by authorizing them to channel "expired" offsets directly to necessary pending projects which are stalled for lack of needed off-

12647 U.S.C. $\$ 301$ (1976). See, e.g., Ashbacker Radio Corp. v. FCC, 326 U.S. 327 (1945).

127 See Red Lion Broadcasting Co. v. FCC, 395 U.S. 367 (1969).

128 FCC v. National Citizens Comm. for Broadcasting, 436 U.S. 775, 805 (1978).

129 The maximum length of time fixed by Pennsylvania for banking of offsets under its proposed scheme is five years. See note 113 supra.

130 For discussion of the purposes and effects of changing the SIP baseline, see text accompanying notes 73-82 supra. 1977).

131 Clean Air Act $\$ 110(\mathrm{a})(2)(\mathrm{H}), 42$ U.S.C. $\$ 7410(\mathrm{a})(2)(\mathrm{H})$ (Supp. I

132 See text accompanying notes 81 \& 82 supra. 
sets. Under this view, the agency would insist upon a transfer, negotiate a fair monetary settlement between the parties, and thereby "free up" offsets to meet a public need. In addition to the difficulty of choosing among competing applicants, especially when an incumbent claims a presumptive right or a renewal expectancy, ${ }^{133}$ however, too many forced transfers would undermine the trading in offsets on the open market. Purchasers would wait and apply for expired offsets at a government-set price rather than at the price which free competition on the open market might have generated. Objections to this procedure are apt to arise among those who stress the ability of the market to allocate optimally offsets ${ }^{134}$ and stimulate conservation measures by the lure of high profits. ${ }^{135}$

A preferable renewal process would have the public authority insist that all expired licenses be auctioned to the highest bidder. ${ }^{130}$ If the parent source wishes to retain its offsets, it will have to pay the going rate to renew them. The difference between the price paid and the parent's original cost of producing the offsets would go to the state to help defray the costs of regulation. If, on the other hand, another enterprise places greater value on the offsets, the parent may drop out of the competition and make a profit.

Such a procedure simultaneously permits market price to allocate offsets free of government interference and has the positive

133 Such decisions to reallocate offset privileges need not be completely arbitrary or discretionary; authorities could promulgate stated criteria and compare competing applicants on the basis of objective social, employment, or tax-based factors. Preference could be given, for example, to the construction or modification which would likely create the most jobs. See Comment, supra note 1, at 595-96. In the absence of such concrete criteria, an agency's decision not to renew an incumbent's license to offset might provoke legal challenges. The experience of the FCC in broadcast licensing suggests that when objective criteria are lacking, comparative licensing hearings are infeasible, see Anthony, Towards Simplicity and Rationality in Comparative Broadcast Licensing Proceedings, 24 StaN. L. Rev. 1, 3-4 (1971), and if renewal becomes the norm, then "a legitimate renewal expectanc[y]" may arise which "should not be destroyed absent good cause." FCC v. National Citizens Comm. for Broadcasting, 436 U.S. 775, 805 (1978) (quoting Greater Boston Television Corp. v. FCC, 444 F.2d 841, 854 (D.C. Cir. 1970), cert. denied, 403 U.S. 923 (1971)). But see Central Fla. Enterprises, Inc. v. FCC, 598 F.2d 37 (D.C. Cir.), cert. denied, 441 U.S. 957 (1979) (remand for failure to articulate basis of decision to renew license). Because construction proposals may be compared more objectively than the content of broadcast programs and do not raise first-amendment considerations, the reluctance of the FCC to deny license renewals might not be duplicated in the context of offset allocation.

134 See T. Morgan, supra note 102 , at 118.

135 See Comment, supra note 1, at 598.

136 See T. MORGAN, supra note 102, at 118 ("If one views the sum a potential user would bid as a measure of the value to him or of the productive use he can make of the resources, then it follows that an auction technique would tend to allocate the scarce resources to the most valuable or productive uses."). 
effect of forcing the sources to meet the current market value of the offsets, thus making them pay some of the "cost" of holding the offset privileges idle. Each time an offset expires and is repurchased by the owner, the owner's "basis" in the offset would be increased to the new purchase price; in this way, an owner would be assessed only for the value increase in his offset since the previous renewal. ${ }^{137}$ With the revenues obtained from the resale of licenses to their original holders, state agencies could occasionally enter the market for offsets and purchase them for use in various community-benefit projects.

As a means of preventing anticompetitive behavior in the offset market, the license model also offers advantages over the privateproperty concept. Rather than having to rely on the case-by-case enforcement of antitrust law to curb monopolistic practices or patterns in the offset market, the states could easily fix upper limits on the amount of offsets licensed to any single source in much the same way that the FCC has averted further concentration of ownership in the media by restricting the number of licenses and newspapers that can be jointly owned. ${ }^{138}$ Indeed, this FCC experience suggests that regulation of entry may justify collateral regulation of broadcaster behavior under a public-interest standard; thus, reasonable rules might be applied to the trading and use of offsets as prophylactic measures. ${ }^{139}$ The threat of having offsets revoked could also serve as a useful enforcement tool to ensure owners' ongoing compliance with restrictions on their already existing sources.

137 To illustrate, assume that $X$ installs a controlling device and produces offsets at a cost of $\$ 100$ in year 1 , whereupon he is issued a five-year license. In order to renew it in year $5, X$ must outbid several competitors. The final purchase price is $\$ 150$, but rather than force $X$ to pay the investment cost of his offsets twice, his out-of-pocket payment in year 5 is only $\$ 50$, the difference between original cost, $\$ 100$, and current market value, $\$ 150$, which goes to the state. By year 10 the value of $X$ 's offsets has increased so that they are now worth $\$ 250$ on the open market. Again $X$ wishes to retain them, so he outbids other buyers and the license is reissued to him for $\$ 250$. Again, in recognition of the private investment which originally created these offsets and to encourage such voluntary offset production, $X$ is charged only the $\$ 100$ by which his offsets have appreciated since the last renewal. When X's license next expires in year 15, holding onto them is no longer worth as much to $X$ as using them is worth to $Y$. The latter wins the bidding by offering to pay $\$ 500$, which goes to $X$ for a net profit of $\$ 250$ ( $\$ 500$ (sale price to $Y$ ) less the sum of $\$ 100$ (cost to $X$ in year 1) plus $\$ 50$ (amount paid to state in year 5 to renew license) plus $\$ 100$ (amount paid to state in year 10 to renew license)).

138 See, e.g., 47 C.F.R. $\$ \$ 73.35,73.240, \& 73.636$ (1979), upheld in FCC v. National Citizens Comm. for Broadcasting, 436 U.S. 775 (1978).

139 The FCC has thus, as an extension of its licensing power, promulgated countless rules regulating the trading and use of, for example, television stations. See, e.g., 47 C.F.R. $\$ \$ 73.1910-.1930$ (1979) (faimess doctrine concerning personal attacks and political editorials); id. $\$ 73.659$ (example of regulation of sale of station). 


\section{Conclusion}

The importance of a workable environmental policy is clear. Such a policy is difficult to obtain, however, because it necessitates a balancing of two legitimate, conflicting interests-protection of the environment and the need for private business to be free from overly burdensome regulation. The emission-offset policy represents a largely successful effort at accommodating these interests. As originally designed, without banking, the offset policy was aimed at encouraging immediate use of offsets in order to ameliorate the economic stagnation that private business had complained was resulting from excessive environmental regulation. With the adoption of offset banking, expansion and construction of new facilities became still more feasible without sacrificing ultimate attainment of clean air.

The banking policy itself, however, leads to another publicprivate conflict with respect to actual ownership of the offsets. Purely private ownership permits businesses to bank offsets for lengthy periods of time, thereby withholding them from productive use and creating a speculative market in offsets that artificially raises their price. In addition, antitrust problems are likely to arise in such a market. On the other hand, purely public ownership of offsets removes all incentives for businesses to reduce emissions beyond what is required by law. Further, allocation of offsets would have to be determined by potentially cumbersome administrative processes rather than by market forces.

This Comment has proposed several alternative solutions to this ownership problem. Although a system of state acquisition and sale of offsets and another model based on the patent system have some attractive features, the most promising proposal involves a licensing system. This method, analogous to regulation of broadcasting, would allow private business to reap profits from its investments while forcing it to assume the cost of holding unused offsets by bidding on the open market to renew its licenses for offsets. Thus, licensing strikes a proper balance between environmental and business interests and offers hope for reducing pollution while contributing to economic vitality. 